\title{
IAMJ
}

INTERNATIONAL

AYURVEDIC

MEDICAL JOURNAL

\section{CLINICAL EFFICACY OF RAJAH PRAVARTINI VATI IN THE MANAGEMENT OF ARTAVA KSHAYA (OLIGOMENORRHOEA)}

\section{Chauhan Monika ${ }^{1}$, Makeem Rita ${ }^{2}$}

Associate Professor, PTSR Dept., Patanjali Ayurveda College, Haridwar, PhD Scholar, Parul Ayurveda College, Vadodara, Gujarat, India

Corresponding Author: Chauhandrmonika1@gmail.com

\section{https://doi.org/10.46607/iamj05p4062020}

(Published online: September 2020)

Open Access

(C) International Ayurvedic Medical Journal, India 2020

Article Received:19/09/2020 - Peer Reviewed:26/09/2020 - Accepted for Publication: 29/09/2020

Check for updates

\begin{abstract}
A clinical trial was carried out on 30 oligomenorrhoea [ArtavaKshaya] patients aged between 18 to 35 years having complaints of irregular, scanty and painful menstruations. The patients were registered from OPD and IPD of Patanjali Ayurveda College, Haridwar. They were administrated Rajahpravartini Vati for three months in a dose of $250 \mathrm{mg}$ twice daily. The specific investigations were done in order to exclude TB endometritis, endocrine disorders, diabetes and heart disease. The clinical assessment was carried out in thirty days intervals. It is inferred that the study discloses the effect of Rajahpravartini Vati on irregularity of interval of menstruation [90.47\%], duration of menstruation [79.37\%], amount of blood flow [90.00\%] and pain during menstruation [100.00\%] which were highly significant in clinical study. No untoward side effect was noticed during clinical trial.
\end{abstract}

Keywords: Oligomenorrhoea, Artavakshaya, Rajahpravartin Vati, Rajadushti, Antahpushpa, Bahirpushpa.

\section{INTRODUCTION}

In the modern world the sedentary lifestyle associated with stress increased menstrual disorders. Among menstrual disorders oligomenorrhea or hypomenor- rhea is the most common gynaecological problems. Ratio of menstrual disorder is rising in gynaecological practice which is a precursor of infertility associated 
with various metabolic disorders, so it requires more attention. Menstrual disorder affects mental state of women. Modern medical science gives Hormonal therapy for menstrual disorders which have many side effects if continued for long time. So, in contemporary era it is very important to provide a particular treatment for "Artavakshaya". In Ayurveda the word Arta$v a$ denotes two meanings, one of them is Antah Pushpa and another one is Bahir Pushpa. Both Antah and Bahir Pushpa are interrelated. Bahir Pushpa is outward manifestation of appropriate work of Antah Pushpa which is necessary for conception. Here, the present studies deal with Bahir Pushpa that is Menstrual Blood. According to Acharya Charaka normal colour of menstrual blood is like Gunjaphala, Lal Kamala (Red lotus flower), Indragopa (An Insect) and Alaktaka ${ }^{1}$. Acharya Sushruta explained that the colour of Shuddhartava should resembles with the ShashaAsrik (Rabbit blood) and Laksha Rasa². Menstrual blood has specific odour. According to Madhukosha Vyakya; Aartava is Madhu Gandhi. Acharya Sushruta says 'Rakta' has Vistrata (Amagandhitva) due to Prithvi Mahabhuta same can be consider for Aartava ${ }^{3}$.Acharya Vagabhata denotes Aartava Pramana measuring to four Anjali. Ayurvedic classics have different opinion regarding duration of menstruation. It describes three (Vagbhata \& Bhavamishra) to five (Charaka)days and rarely up to seven (Harita \& Bhela) days. The abnormal menstrual flow indicates scanty menstrual flow both in amount and duration with associated symptom of pain in lower abdomen or back or vagina ${ }^{4}$ and can be counted as Vataja $R a$ jadushti, ${ }^{5}$ Kshinartava $^{6}$ and Artavakshaya ${ }^{4}$ in Ayurveda classic. It may be due to nutritional deficiency or decrease in Rasa and Rakta Dhatu and Upadhatu (Raja/Artava) and hormonal deficiency and it can be compared with oligomenorrhoea or hypomenorrhoea described in modern medical science, in which hormonal disorders occurs due to underproduction of the endometrium and lack of co-ordination of hypothalamo-pituitary ovarian axis. ${ }^{7}$ The aforesaid three are indicators of abnormal menstrual flow, Artavakshaya, that is covered in this feature and captioned as the title of the research profile. According to Acharyas, Ar- tavakshaya is a complication of Rasa and Raktakshaya due to vitiation of Vatadosha. ${ }^{8}$ So the treatment should be Vatashamaka and Agnivardhaka., The aim of this study is to establish an Ayurvedic medication as a remedy of Artavakshaya in reproductive life of women which mimics the normal life span of present era

Need of Present Research Work On account of modernization \& urbanization, there is intake of spicy diet, fried food, stress \& social problems, the menstrual disorders have become a very challenging problem for working ladies or housewives. iii They may involve the structural or functional disturbances and are mostly associated with the complaint of infertility, obesity etc. Now a days, in modern science, scanty \& infrequent menstruation is treated by hormonal therapy \&long-term use of these drugs produce many side effects. So, it is very essential to find out some effective Ayurvedic medicine for this condition. Ayurvedic management seems to be more practical, effective, not costly, non-surgical and have negligible side effects.

\section{Materials and Methods}

Selection of patients: Thirty oligomenorrhoea (Artava Kshaya) patients of age group 18 to 35 years, complaint with irregular, scanty and painful menstruation, were enrolled from OPD and IPD of Patanjali Ayurveda college and hospital, Haridwar, Detailed history, complete general systemic and gynecological examinations, $(\mathrm{P} / \mathrm{A} \mathrm{P} / \mathrm{S}, \mathrm{P} / \mathrm{R}$ - in case of virgins and unmarried girls) were done for every cases. The patients diagnosed as Tubercular Endometritis, Poly cystic ovarian syndrome, Thyroid, Pituitary and Hypothalamic abnormalities, general diseases like Tuberculosis, Nephritis, Diabetes, VDRL, and Heart diseases were excluded from this clinical study. All selected patients were advised to attend in 30 days interval regularly for 3 months. During the follow up time, all required investigations were also recorded.

\section{Selection of drug}

Rajah Pravartini Vati is used for the treatment of women's health problems. It is likely to stimulate the ovulation and corrects the ovarian functions. It also promotes the menstrual discharge due to its emmenagogue action. It is helpful in the treatment of amenor- 
rhea, oligomenorrhea, dysmenorrhea associated with light menstruation or scanty periods and backache during menstruation. It is beneficial when patient feel outflow obstruction during menstruation.

\section{Ingredients (Composition) $)^{11}$}

\begin{tabular}{|l|l|}
\hline Ingredients & Quantity \\
\hline Elwa (Musabbar) - Aloe Vera (Indian Aloe) Extract & 1 Part \\
\hline Roasted Hing (Asafoetida) - FerulaAssa-Foetida) & 1 Part \\
\hline Shuddha Tankan (Tankan Bhasma) & 1 Part \\
\hline ShuddhaKasis (or KasisBhasma) & 1 Part \\
\hline
\end{tabular}

Reference: Bhaishajya Ratnavali, Chapter 67, Yonivyapad, Verse 58-60

Preparation of RajahPravartini Vati: All the ingredients should undergo Shodhanvidhi and mixed together by triturating in Khalva yantra. Then it should be lavigating (bhavana) with Kumari swarasa for one day. Prepare its pill for two Ratti (250 mg). These pills prepared in uniform size and dry them in shade. After drying pills were stored in glass bottles.

Pharmacological Actions: Rajah PravartiniVati as given in BHAISHAJYA RATNAVALI is USHNA (Hot) potency. Ingredients in it possess potent emmenagogue action and promote the menstrual flow by releasing the flow obstruction in menstruation due to increased Kapha and aggravated Vata. It pacifies Kapha Dosha and Vata Dosha, but it increases Pitta Dosha.

Medicinal Properties: Emmenagogue, Carminative, Antispasmodic, Haematinic (increases hemoglobin levels), Mild Anodyne, Mild Laxative, Uterine detoxifier.

Therapeutic Indications: Amenorrhea, Oligomenorrhea, Dysmenorrhea associated with light menstruation or scanty periods. Rajah Pravartini Vati induces menstruation and promotes menstrual flow. Its ingredients like Kasis and Asafoetida possess potent emmenagogue property. This action also helps to treat Oligomenorrhea. Rajah PravartiniVati should be started in a dosage of $250 \mathrm{mg}$ twice daily for three months. All patients were advised to take same diet till the end of trial.

Investigations: Hemoglobin gm\% (Sahilis method) and weight in kilogram of the patient were collected from each patient on the first day of clinical trial and each follow up period in 30 days interval for three consecutive follow up period.

Assessment of Progress: Two parameters - Subjective and Objective, were used in initial and consecutive follow up time for assessment of progress. The subjective parameters were interval of menstruation, duration of menstruation and pain throughout menstruation period. The objective parameters were amount of blood flow by using pad, hemoglobin in gm $\%$ and weight in kilogram of the patients. The assessments were separated by grading $0,1,2,3$, on the basis of days of interval, duration and painful menstruation and increasing $\mathrm{Hb} \mathrm{gm} \%$ and weight gain.

Overall Effect of Therapy: In view of changes in grade of clinical features, it was declared as follows, Complete cure 100\% free from chief complaint (irregular, scanty and painful menstruation and pain in back and lower abdomen), Maximum improvement - 75\% to $<100 \%$ improvement of the clinical features. Moderate improvement $-50 \%$ to $<75 \%$ improvement of the clinical features., Mild improvement - $25 \%$ to $<50 \%$ improvement of the clinical features., No improvement - $<25 \%$ or no improvement in both subjective and objective parameters.

Observation and Results: It was observed that out of 30 patients maximum number of patients $(40 \%)$ was enrolled at the age from 30 to 35 years [Table 1]. The unmarried [Table 2] and middle-class economic status patients [Table 3] were more affected with oligomenorrhoea/ The chronicity of disease was observed more in more than six months [Table 4] of attack. Among the clinical features, painful menstrual bleeding [Table 5] was found more rather than other fea- 
tures/ The assessment of progress of result [Table 7] was inferred from $1^{\text {st }}$ follow up period and $60 \%$ pa- tients were under the category of moderate improvement.

Table 1: The incidence of age groups $(n=30)$

\begin{tabular}{|l|l|l|}
\hline Age group in years & No. of Patients & Percentage \\
\hline $18-20$ & 8 & 27 \\
\hline $21-25$ & 7 & 23 \\
\hline $26-30$ & 3 & 10 \\
\hline $31-35$ & 12 & 40 \\
\hline Total & 30 & 100 \\
\hline
\end{tabular}

Table 2: The incidence of marital status $(n=30)$

\begin{tabular}{|l|l|l|}
\hline Marital Status & No. of Patients & Percentage \\
\hline Married & 12 & 40 \\
\hline Unmarried & 18 & 60 \\
\hline Total & 30 & 100 \\
\hline
\end{tabular}

Table 3: The incidence of economic status $(n=30)$

\begin{tabular}{|l|l|l|}
\hline Economic Status & No. of Patients & Percentage \\
\hline Poor & 10 & 33 \\
\hline Middle & 12 & 40 \\
\hline Higher & 8 & 27 \\
\hline Total & 30 & 100 \\
\hline
\end{tabular}

Table 4: The incidence of chronicity of disease $(n=30)$

\begin{tabular}{|l|l|l|}
\hline Chronicity in Months & No. of Patients & Percentage \\
\hline $01-<6$ & 10 & 33 \\
\hline $07-<12$ & 12 & 40 \\
\hline$>12$ & 8 & 27 \\
\hline Total & 30 & 100 \\
\hline
\end{tabular}

Table5: The incidence of clinical features $(n=30)$

\begin{tabular}{|l|l|l|}
\hline Clinical features & No. of Patients & Percentage \\
\hline Irregular menstrual cycle & 21 & 70 \\
\hline Painful menstrual bleeding & 28 & 93 \\
\hline Scanty menstrual bleeding & 24 & 80 \\
\hline Pain (backache) & 17 & 57 \\
\hline Pain (lower abdomen) & 27 & 90 \\
\hline General weakness & 15 & 50 \\
\hline
\end{tabular}

Table 6 The incidence of clinical assessments of result $(n=30)$

\begin{tabular}{|l|l|l|l|}
\hline Clinical assessment of results & $\begin{array}{c}\text { At first month No. } \\
\text { Pts. (\%) }\end{array}$ & At second month No. of Pts. (\%) & $\begin{array}{l}\text { At third month No. of Pts. } \\
(\%)\end{array}$ \\
\hline Cure & 00 & 00 & 00 \\
\hline Maximum improvement & 00 & 026.7 & $06-20$ \\
\hline Moderate improvement & $02-6.7$ & $11-37$ & $18-60$ \\
\hline Mild improvement & $16-53$ & $12-40$ & $05-17$ \\
\hline Unsatisfactory & $12-40$ & $05-17$ & $01-3.3$ \\
\hline Total & $30-100$ & $30-100$ & $30-100$ \\
\hline
\end{tabular}


Table 7 Effect of Therapy on clinical features $(n=30)$

\begin{tabular}{|l|l|l|c|c|}
\hline Clinical features & BT $($ Mean \pm SD & AT $($ Mean \pm SD $)$ & 't' & P \\
\hline Irregular menstrual cycle & $21.86 \pm 2.48$ & $23.16 \pm 1.94$ & 2.89 & $<0.01$ \\
\hline Painful menstrual cycle & $2.73 \pm 2.03$ & $1.17 \pm 0.91$ & 4.13 & $<0.05$ \\
\hline Scanty menstrual bleeding & $9.3 \pm 4.61$ & $14.23 \pm 3.11$ & 1.26 & $<0.001$ \\
\hline Pain(backache) & $1.2 \pm 0.56$ & $0.98 \pm 0.39$ & 1.01 & $>0.10$ \\
\hline Pain (lower abdomen) & $2.4 \pm 1.03$ & $2.11 \pm 0.97$ & 1.12 & $>0.10$ \\
\hline Anaemia (Hb gm\%) & $10.46 \pm 2.09$ & $11.29 \pm 1.94$ & 0.89 & $>0.10$ \\
\hline Weight & $39.78 \pm 5.39$ & $40.43 \pm 4.12$ & $>0.10$ \\
\hline
\end{tabular}

BT-Mean score before treatment, AT-Mean score after treatment, SD-Standard deviation, $\mathrm{P}<0.05=$ Significant

\section{DISCUSSION}

Artava Kshaya is one of the menstrual disorders which indicate scanty menstrual flow associated with pain in variable duration where vitiation of Vayu and Kapha are predominant. Artava is an Upadhatu, formed from Rasa within a month after proper metabolization of Rakta dhatu by its Dhatwagni and Bhutagni. ${ }^{8}$ The decrease or kshaya of Rakta dhatu causes Artavakshaya and simultaneously Raktakshaya is developed. ${ }^{9,12}$ Rajahpravartini Vati comprising Vata and Kapha Dosha shaman drugs and the drug which increases the Agneyaguna, Vriddhi of Pitta also be useful for Artavajanana. In the present study, it was observed that the maximum numbers of patients $(40 \%)$ were under the age of 31-35 years [Table 1]. The above age group is considered as the late reproductive age while usually physiological hormonal changes occur. The maximum numbers of unmarried patients $(60 \%)$ were registered. It shows that this disorder is common in unmarried life, may be due to psychological stress, over consciousness, shyness and spices pungent sour diet which change the physiological hormone leading to less production of Artava. Among the clinical features, painful menstrual bleeding (93\%) was found [Table 5] more. It may be due to overload of education, inadequate formation of hormone and inadequate taking of food. After administration of trial drug, satisfactory significant result $(t=2.89, P<0.01)$ for painful menstrual bleeding was observed. Scanty menstrual bleeding was observed in $80 \%$ of patients [Table 5]. After taking drugs, result was highly significant $(t=4.13, P<0.001)$. Irregular menstrual cycle was also observed in $70 \%$ patients. After medication, a satisfactory significant result was observed $(t=2.89$,
$P<0.01)$. Pain in lower abdomen and back were also observed in 90 and $57 \%$ respectively, but statistically result was not satisfactory. There was an increase in $\mathrm{Hb} \mathrm{gm} \%$ in all the cases. It may be due to Agni and pitta vitiated effects of Rajahpravartini Vati but significant result was not observed. The statistical evaluation of clinical study revealed that significant results were observed [Table 7] in painful menstrual bleeding, scanty menstrual bleeding and irregular menstrual cycle. Improvements were revealed in reducing pain in back and lower abdomen, but statistical results were unsatisfactory. The overall result [Table 6] of the present clinical study shows that six $(20 \%)$ cases were shown maximum improvement, $18(60 \%)$ cases were moderately improved whereas mild improvement was noted in five $(16.67 \%)$ cases and only one $(3.33 \%)$ case showed unsatisfactory result after completion of the clinical trial.

\section{CONCLUSION}

In nutshell, this clinical study was conducted on the basis of the aforesaid parameters, and encouraging result was inferred by the treatment of Ayurvedic drug, RajahPravartini Vati in Artavakshaya patients. Being chief, easily available, effective, nontoxic and safe, the Rajah Pravartini Vati can be utilized in $\mathrm{Ar}$ tavakshaya. However, this is a preliminary study; further study is required to establish its action on hormones interference in menstruation. No untoward side effect was observed in this clinical study.

\section{REFERENCES}

1. Charak, Caraksamhita of Agnivesh, edited with Vaidya Manorama hindi commentary by Acharya S. Vidyadhara and prof. T. Ravi Dutt, forwarded by Acharya 
S. Priya Vrat, Chaukhamba Sanskrit Prakashan, Delhi, reprint 2010, chikitsasthan 30/226. p.no.780.

2. Sushruta, Sushruta Samhita, edited by Acharya S. Priya Vrat., Chaukhambha Surabharati, Varanasi 2009, Sharirsthan 2/19, p.no.16

3. Sushrut, Sushrutsamhita, sushrutvimarshini hindi vyakhya by S. Anantram edited by Acharya Priyavrat Sharma, Chaukhamba Surbharti Prakashan, Varansi, reprint 2009; sutrasthan 14/9, p.no.101.

4. Varanasi: Chaukhamba Sanskrit Pratisthana; 1978. Sushruta Samhita Sutra Sthana Adyaya 15/12 with Govinda Bhaskara Ghanekar comm; p. 92.

5. Varanasi: Chaukhamba Sanskrit Pratisthana; 1978. Sushruta Samhita Sutra Sthana Adyaya 2/4 with Govinda Bhaskara Ghanekar comm; p. 13

6. Gupta A, editor. Varanasi: Chaukhamba Sanskrit Sansthana; 1991. Asthanga Hrudaya Sharira Sthana Adhyaya 1/11 with Vidyotini Hindi comm; p. 361.

7. Dutta DC. 2nd ed. New Delhi: New Central Book Agency (p) Ltd; 1994. Textbook of Gyanaecology; p. 174.

8. Gupta A, editor. Varanasi: Chaukhamba Sanskrit Sansthana; 1991. Asthanga Hrudaya Sharira Sthana Adhyaya 1/24 with Vidyotini Hindi comm; p. 364.

9. Tiwari P. 2nd ed. Varanasi: Chaukhamba Orientalia; 2007. Ayurvedeeya Prasutitantra AvamStree Roga; p. 9

10. Kashyapa Samhita. 7th ed. Varanasi: Chowkhamba Sanskrit Pratisthana; 1994. Vidyotini Hindi Commentary; p. 184.

11. Shastri V K A. Baishajyaratnalavali, Ayurved acharya R D S. Varanasi, chowkhamba samskrithasamstana, 41st Chapter, $20^{\text {th }}$ shloka, page-314

12. Joshi NG. 2nd ed. Varanasi: Chowkhamba Sanskrit Pratisthana; 2006. Ayurvediya Concepts in Gynaecology; p. 42.

\section{Source of Support: Nil \\ Conflict of Interest: None Declared}

How to cite this URL: Chauhan Monika \& Makeem Rita: Clinical Efficacy of Rajah Pravartini Vati in the Management of Artava Kshaya (Oligomenorrhoea). International Ayurvedic Medical Journal \{online\} 2020 \{cited September, 2020\} Available from: http://www.iamj.in/posts/images/upload/2480_2485.pdf 